\title{
Teacher's Role in Interactive Multimedia Development (An Overview of Teacher Competencies and Its Relation to Interactive Media)
}

\author{
Huriyah Padhilah Anasti \\ Master Program, Faculty of Language and Arts, Padang State University
}

3030huri@gmail.com

Learning media is the most important part in a learning process. Learning media is a tool used to assist the teaching and learning process. The purpose of using learning media is to stimulate learning patterns in order to achieve learning success and achieve the desired goals (Setiawan et al., 2021: 47). The learning media used must vary along with the rapid development of the times (Novelti et al., 2018: 112). At this time we have arrived at the 21 st century learning paradigm education which requires educators to be able to create the latest innovations in the learning process to improve learning achievement (Mulyadi et al., 2020: 1). One of the learning media innovations needed at this time considering the COVID-19 pandemic is technology-based media. Media is developed to suit the needs of today's students by utilizing technological devices. Many formal education environments today require learning to be done online. Therefore, learning must be developed so that it can be used by students in the context of digital learning or online learning (Atmazaki et al., 2021: 3). In addition, technology-based learning media for students can grow their positive attitude towards the material and the continuity of the learning process (Mulyadi et al., 2020: 2).

The form of technology-based learning media that is suitable for use during the covid-19 pandemic is one of them interactive multimedia learning media. Terentyeva (in Ramadhan, 2020: 2) states that the use of multimedia allows learning to take place in a computerized classroom or at home. So it is also possible to be adapted in distance learning. Zamzam (2021: 2) defines interactive multimedia as a learning media that combines various media in the form of images, text, audio or animation that are interactive with the aim of providing information. Rachmadtullah and Sumantri and Ramadhani and Muhtadi (in Nuraini et al., 2021: 34) state that interactive multimedia is used by utilizing computer media as a support in the learning process, or can also use smartphones or androids. Yuong (in Mulyadi et al., 2020:2) states that the use of multimedia in learning provides opportunities, especially for students and teachers to develop learning 
techniques that are in accordance with the objectives to achieve maximum learning outcomes. Meanwhile, according to Pranata (in Zamzam, 2021: 2) utilizing interactive multimedia as an instructional tool can form the independence of students. In line with this opinion, Munir (in Apriati et al., 2021: 14) states several reasons for the importance of learning using interactive multimedia are: (a) the message in the material delivered feels more real, (b) the media stimulates various senses so that between the senses occurs an interaction, (c) visualization in the form of text, images, audio, video, and animation for students will be easier to remember and capture, (d) learning using mobile technology makes learning more practical and controlled, and (e) time, cost , and more energy efficient.

In learning Indonesian, learning media in the form of interactive multimedia is very necessary in distance learning (online) at this time. This is considering that learning Indonesian includes 4 aspects of language skills that must be mastered by students. Kharade \& Peese (in Ramadhan et al., 2018: 195) state that language learning is a complex process that includes various dimensions in the form of intellectual, social and emotional dimensions. It can be said that teaching both Indonesian and any language is a multidimensional activity, so that language learning that takes place must be able to be designed by the teacher so that multidimensional activities can be realized. One of the characteristics possessed by interactive multimedia learning media is very suitable for language learning. Andajani and Heinich et al., (in Apriati et al., 2021: 16) state that interactive multimedia is not only limited to showing media or objects to students, but students are also required to interact during learning. The use of interactive multimedia-based media for language learning has been proven in a study by Mulyadi et al. (2018) which obtained the results that learning Indonesian by using interactive multimedia-based e-modules that took place for students at IAIN Bukittinggi was very effective. Interactive multimedia e-modules can also improve learning achievement and interest in learning.

The development and use of interactive multimedia-based learning media certainly cannot be separated from the competencies possessed by the teacher. This is because the teacher plays a role in all forms of the learning process. According to Hoydalsvik (in Indriyani et al., 2019: 110) teachers are actors in change, teachers take part in the policy development process. Another opinion that confirms this is that the competence possessed by the teacher gives an overview of his ability to carry out his duties professionally or vice versa (Linda and Ngazizah, 2021: 59). 
Professional teachers are the key in implementing quality education in schools (Lahami, 2021: 14). Professional teachers must be able to adapt to technological developments as reflected in their ability to utilize digital media and learning resources (Agusrida et al., 2020: 370-371). Therefore, it is highly expected that there are professional teachers in the development of interactive multimedia-based learning media. Supriyanto (in Supriatna, 2021:215) states that the competence

of teachers to develop learning media based on information and communication technology is very important for the implementation of effective online learning. But it is unfortunate that in fact according to Levitskaya \& Seliverstova (in Supriatna, 2021: 215) that teacher competence in utilizing information and communication technology in learning is not sufficient, there are still many teachers who use technology in a simple way and tend to carry out traditional learning. Based on this, it can be concluded that the competence and professionalism of teachers in the development of interactive multimedia-based learning media must be further improved, considering that teachers play an important role in the development of these learning media.

\section{Reference:}

Agusrida, Atmazaki, Ramadhan, S., dan Ermanto. (2020). Effectiveness of Online Scientific Publication Training Approach for Teacher's Professional Competence Development at Religious Training Centre in Padang. Atlantis Press, 370-375.

Apriati, L., Mulawarman, W. G., dan Ilyas, M. (2021). Pengembangan Bahan Ajar Menyimak Berbasis Multimedia Interaktif pada Pembelajaran Tematik dengan Tema "Indahnya kebersamaan” untuk Siswa Kelas VI Sekolah Dasar. Diglosia, 4(1), 13-22.

Atmazaki, Ramadhan, S., Indriyani, V., dan Nabila, J. (2021). Dialogic-Interactive Media Design for Language Learning to Improve Speaking Activites and Skills. IOP Publishing, 1-9.

Indriyani, V., Zaim, M., Atmazaki, dan Ramadhan, S. (2019). Literasi Baca Tulis dan Inovasi Kurikulum Bahasa. Kembara: Jurnal Keilmuan Bahasa, 5(1), 108-118.

Lahami, M. A. G. (2021). Pengaruh Workshop Media Pembelajaran terhadap Peningkatan Kompetensi Guru dalam Mengembangkan Media Pembelajaran. JETCLC: Journal of Educational Technology, Curriculum, Learning, and Communication, 1(1), 13-21.

Linda, R. F. C., dan Ngazizah, N. (2021). Kompetensi Guru terhadap Pembelajaran Daring pada Masa Pandemi Covid-19. At-Thullab: Jurnal Pendidikan Guru Madrasah Ibtidaiyah, 5(1), 57-74. 
Mulyadi, Atmazaki, Ramadhan, S., dan Agustina. (2018). The Development of Interactive Multimedia E-Module on Indonesia Language Course. Atlantis Press, 291-295.

Mulyadi, Ramadhan, S., Atmazaki, dan Agustina. (2020). The Development of E-Modules Based on Adobe Flash for Indonesia Subjects at IAIN Bukittinggi. IOP Publishing, 1-8.

Novelti, Ramadhan, S., Ermanto, dan Agustina. (2018). Developing in Instructional Model Assisted Audio Visual Media. Atlantis Press, 111-116.

Nuraini, M. F. (2021). Pengembangan Multimedia Interaktif Materi Perubahan Wujud Benda Bagi Siswa Sekolah Dasar. JKTP: Jurnal Kajian Teknologi Pendidikan, 4(1), 33-40.

Ramadhan, S., Asri, Y., dan Indriyani, V. (2018). Learning Module Design Writing Argumentative Text Based Problem-Based Learning. Atlantis Press, 194-200.

Ramadhan, S., Atmazaki, Sukma, E., dan Indriyani, V. (2020). Multimedia with Social Learning Nerwork (SNL): As Learning Innovation in the 4.0 Industrial Era. IOP Publishing, 1-9.

Setiawan, B., Pramulia, P., Kusmaharti, D., Juniarso, T., dan Wardani, I. S. (2021). Peningkatan Kompetensi Guru Sekolah Dasar dalam Pengembangan Media Pembelajaran Daring SDN Morgorejo 1 Kota Surabaya. Manggali, 1(1), 46-57.

Supriatna, U. (2021). Kompetensi Guru Memanfaatkan Teknologi Informasi dan Komunikasi dalam Mengembangkan Media Pembelajaran Online. Edumaspul, 5(1), 214-221.

Zamzam, K. F. (2021). Pengembangan Multimedia Interaktif Geometri Transformasi Berbasis Discovery Learning dengan Pendekatan Kontekstual. JPIn: Jurnal Pendidikan Indonesia, 4(1), 19. 